\title{
OPEM
}

www.opem.org

Oriental Pharmacy and Experimental Medicine 2008 7(5), 540-548

DOI 10.3742/OPEM.2008.7.5.540

\section{Aqueous extract of Paeonia radix suppresses lipopolysaccharide-induced expressions of cyclooygenase-2 and inducible nitric oxide synthase in mouse BV2 microglial cells}

\author{
Sung-Kwan Hong ${ }^{1}$, Youn-Sub Kim ${ }^{1}$, Hye-Young Yang' ${ }^{2}$ Hyun-Kyung Chang ${ }^{2}$, Yu-Mi Kim², Mal- \\ Soon Shin ${ }^{2}$, Seung-Soo Baek ${ }^{3}$ and Chang-Ju Kim ${ }^{2, *}$ \\ ${ }^{1}$ Department of Anatomy-Pointology, College of Oriental Medicine, Kyungwon University, 65 Bokjung-dong, \\ Sujung-gu, Songnam 461-701, Republic of Korea; ${ }^{2}$ Kohwang Medical Research Institute, Department of Physiology, \\ College of Medicine, Kyung Hee University, 1 Hoigi-dong, dongdaemoon-gu, Seoul 130-701, Republic of Korea; \\ ${ }^{3}$ Department of Physical Education, College of Arts and Physical Education, Sang Myung University, 7 Hongji-dong, \\ Jongno-gu, Seoul 110-743, Republic of Korea
}

\begin{abstract}
SUMMARY
Paeonia radix is the root of Paeonia aliflora Pallas, which is a perennial plant classified in the family Paeoniaceae. Paeonia radix possesses several pharmacological effects such as analgesic, antiinflammatory and anti-allergic, anti-oxidative, and anti-coagulant activities. In this study, we investigated the effect of the aqueous extract of Paeonia radix on the lipopolysaccharide-induced inflammation in mouse BV2 microglial cells. The aqueous extract of Paeonia radix at respective concentration was treated one hour before lipopolysaccharide treatment. In the present results, the aqueous extract of Paeonia radix suppressed prostaglandin $\mathrm{E}_{2}$ synthesis and nitric oxide production by inhibiting the lipopolysaccharide-stimulated mRNA expressions of cyclooxygenase-2 and inducible nitric oxide synthase in mouse BV2 microglial cells. These results demonstrate that Paeonia radix exerts anti-inflammatory and analgesic effects probably by suppressing mRNA expressions of cyclooxygenase- 2 and inducible nitric oxide synthesis. The present study demonstrates that Paeonia radix may offer a valuable mean of therapy for brain inflammatory diseases.
\end{abstract}

Key words: Paeonia radix; Lipopolysaccharide; Cyclooxygenase-2; Prostaglandin $\mathrm{E}_{2}$; Inducible nitric oxide synthase; Nitric oxide

\section{INTRODUCTION}

Paeonia radix is the root of Paeonia aliflora Pallas, which is a perennial plant classified in the family Paeoniaceae. Paeony plants, such as Paeonia radix, have been used for a lot of therapeutic purpose in traditional medicine. Paeonia radix possess several

\footnotetext{
*Correspondence: Chang-Ju Kim, Department of Physiology, College of Medicine, Kyung Hee University, 1 Hoigidong, Dongdaemoon-gu, Seoul 130-701, Republic of Korea. Tel: +8229610407; Fax: +8229642195; E-mail: changju@khu.ac.kr
}

pharmacological effects such as analgesic (Sugishita et al., 1984), anti-inflammatory and anti-allergic (Yamahara et al., 1982), anti-oxidative (Kim et al., 1998), anti-coagulant activities (Ishida et al., 1987), and inhibitory action on steroid protein binding (Tamaya et al., 1986).

Microglia are considered resident immune cells in central nervous system (CNS) (Liu and Hong, 2003), and they are activated in response to infection or brain injury (Kreutzberg, 1996). The major factors produced by activated microglia are tumor necrosis factor- $\alpha$ (TNF- $\alpha)$, interleukins, nitric 
oxide (NO), prostaglandin $\mathrm{E}_{2}\left(\mathrm{PGE}_{2}\right)$, leukotrienes, growth factors, and fatty acid metabolites such as eicosanoids. Microglia activation in the CNS is associated with neurodegenerative disorders and release of proinflammatory cytokines (Boje and Arora, 1992; Chao et al., 1992; Gonzalez-Scarano and Baltuch, 1999).

Pain is the first response to injury or infection. Injury and infection activate the immune system to produce inflammatory responses (Dickerson $e t$ al., 1998). Lipopolysaccharide (LPS) initiates a number of major cellular responses that play vital roles in the pathogenesis of inflammatory response. LPS stimulates the production of inflammatory mediators such as NO, TNF- $\alpha$, interleukins, $\mathrm{PGE}_{2}$, and leukotrienes (Lee et al., 1992; Kubes and McCafferty, 2000). Moreover, LPS enhances the pain response to various somatic stimuli (Watkins et al., 1994; Yirmiya et al., 1994).

$\mathrm{PGE}_{2}$ is a key inflammatory mediator, and an increased level of $\mathrm{PGE}_{2}$ mediates the cardinal features of inflammation such as pain, edema, and fever (Coleman et al., 1994; Tilley et al., 2001). $\mathrm{PGE}_{2}$ is converted from arachidonic acid by cyclooxygenase (COX). There are two isoforms of COX: COX-1 and COX-2. COX-1 is a constitutively expressed form in normal physiologic functions, while COX-2 is expressed only in response to inflammatory signals such as cytokines and bacterial endotoxin, LPS. COX-2 produces large amount of $\mathrm{PGE}_{2}$ that induces inflammation (Mitchell et al., 1995; Crofford et al., 2000).

$\mathrm{NO}$ is synthetized from L-arginine by nitric oxide synthase (NOS). NO plays an important role in the regulation of many physiological processes (Dawson et al., 1992). There are three distinct isoforms of NOS: neuronal NOS (nNOS), inducible NOS (iNOS), and endothelial NOS (eNOS). Of these, iNOS is an important enzyme involved in the regulation of inflammation (Yui et al., 1991), and LPS upregulates iNOS expression in macrophages (Korhonen et al., 2002) and microglial cells (Vegeto et al., 2001).
In the present study, we investigates the effects of the aqueous extract of Paeonia radix from Paeonia aliflora Pallas on the LPS-stimulated mRNA expressions of COX-1, COX-2, and iNOS in mouse BV2 microglial cells by using 3-(4,5-dimethylthiazol-2yl)-2,5-diphenyltetrazolium bromide (MTT) assay, reverse transcription-polymerase chain reaction (RT-PCR). The effects of Paeonia radix on the $\mathrm{PGE}_{2}$ synthesis and the NO production were also studied by performing $\mathrm{PGE}_{2}$ immunoassay and by detecting NO.

\section{MATERIALS AND METHODS}

\section{Aqueous extraction of Paeonia radix from Paeonia aliflora pallas}

Paeonia radix used in this experiment was obtained from the Kyungdong market (Seoul, Republic of Korea). To obtain the aqueous extract of Paeonia radix, $200 \mathrm{~g}$ of Paeonia radix was added to distilled water, and extraction was performed by heating at $80^{\circ} \mathrm{C}$ for $2 \mathrm{~h}$ with distill water, pressure-filtered, concentrated by using a rotary evaporator (Eyela, Tokyo, Japan). The resulting powder weighing $17.3 \mathrm{~g}$ (a yield of $8.65 \%$ ) was obtained though lyophilization by a freezing drier (llsin, Kyungkido, Republic of Korea) for $24 \mathrm{~h}$. The aqueous extract of Paeonia radix at the respective concentration was treated one hour before the LPS treatment in mouse BV2 microglial cells.

\section{Cell culture}

Mouse BV2 microglial cells were cultured in Dulbecco's modified Eagle's Medium (DMEM; Gibco BRL, Grand Island, NY, USA) supplemented with $10 \%$ heat-inactivated fetal bovine serum (FBS; Gibco BRL) at $37^{\circ} \mathrm{C}, 5 \% \mathrm{CO}_{2}$ in a humidified cell incubator. The cells were plated onto culture dishes at a density of $2 \times 10^{4}$ cells $/ \mathrm{cm}^{2}$ at $24 \mathrm{~h}$ prior to drug treatment.

\section{MTT cytotoxicity assay}

Mouse BV2 microglial cells were grown in a final 
volume of $100 \mu \mathrm{l}$ culture medium per well in a 96well plate. In order to determine the cytotoxicity of Paeonia radix, the cells were treated with Paeonia radix at concentrations of $0.1 \mu \mathrm{g} / \mathrm{ml}, 1 \mu \mathrm{g} / \mathrm{ml}, 10$ $\mu \mathrm{g} / \mathrm{ml}, 100 \mu \mathrm{g} / \mathrm{ml}$, and $1,000 \mu \mathrm{g} / \mathrm{ml}$ for $24 \mathrm{~h}$. The cells in the control group were left untreated. After adding $10 \mu \mathrm{l}$ of the MTT labeling reagent containing $5 \mathrm{mg} / \mathrm{ml}$ of MTT in phosphate-buffered saline (PBS) to each well, the plate was incubated for $4 \mathrm{~h}$. Solubilization solution $100 \mu \mathrm{l}$ containing $10 \%$ sodium dodecyl sulfate (SDS) in $0.01 \mathrm{M}$ hydrochloric acid was added to each well, and the cells were incubated for another $12 \mathrm{~h}$. The absorbance was then measured with a microtiter plate reader (BioTek, Winooski, VT, USA) at a test wavelength of $595 \mathrm{~nm}$ with a reference wavelength of $690 \mathrm{~nm}$. The optical density (O.D.) was calculated as the difference between the absorbance at the reference wavelength and that observed at the test wavelength. Percent viability was calculated as (O.D. of drugtreated sample/control O.D.) $\times 100$.

\section{RNA isolation and RT-PCR}

To identify the mRNA expressions of COX-1, COX-2, and iNOS, RT-PCR was performed. The total RNA was isolated from BV2 cells using $\mathrm{RNAzol}^{\mathrm{TM}} \mathrm{B}$ (TEL-TEST, Friendswood, TX, USA). Two $\mu \mathrm{g}$ of RNA and $2 \mu \mathrm{l}$ of random hexamers (Promega, Madison, WI, USA) were added together, and the mixture was heated at $65^{\circ} \mathrm{C}$ for $15 \mathrm{~min}$. One $\mu \mathrm{l}$ of AMV reverse transcriptase (Promega), $5 \mu$ of $10 \mathrm{mM}$ dNTP (Promega), $1 \mu \mathrm{l}$ of RNasin (Promega), and $5 \mu \mathrm{l}$ of 10 AMV RT buffer (Promega) were then added to the mixture, and the final volume was brought up to $50 \mu \mathrm{l}$ volume with diethylpyrocarbonate (DEPC)-treated water. The reaction mixture was then incubated at $42^{\circ} \mathrm{C}$ for $2 \mathrm{~h}$.

PCR amplification was performed in a reaction volume of $40 \mu \mathrm{l}$ containing $1 \mu \mathrm{l}$ of the appropriate cDNA, $1 \mu \mathrm{l}$ of each set of primers at a concentration of $10 \mathrm{pM}, 4 \mu \mathrm{l}$ of $10 \times$ RT buffer, $1 \mu \mathrm{l}$ of $2.5 \mathrm{mM}$ dNTP, and 2 units of Taq DNA polymerase (Takara, Shiga, Japan). For mouse COX-1, the primer sequences were 5'-AGTGCGGTCCAACCTTATCC3' (a 20-mer sense oligonucleotide) and 5'CCGCAGGTGATACTGTCGTT-3' (a 20-mer antisense oligonucleotide). For mouse COX-2, the primer sequences were 5'- CCAGATGCTATCTTTGGGGAGAC-3' (a 23-mer sense oligonucleotide) and 5'- CTTGCATTGATGGTGGCTG -3' (a 19-mer anti-sense oligonucleotide). For mouse iNOS, the primer sequences were 5'-ATGAGGTACTCAGCGTGCTCCAC-3' (a 23-mer sense oligonucleotide) and 5'-CCACAATAGTACAATACTACTTGG-3' (a 24-mer anti-sense oligonucleotide). For cyclophilin, the internal control used in the study, the primer sequences were 5'-ACCCCACCGTGTTCTTCGAC3' (a 20-mer sense oligonucleotide) and 5'CATTTGCCATGGACAAGATG-3' (a 20-mer antisense oligonucleotide). The expected size of the PCR product was $381 \mathrm{bp}$ for COX-1, $249 \mathrm{bp}$ for COX-2, $395 \mathrm{bp}$ for iNOS, and $299 \mathrm{bp}$ for cyclophilin.

For COX-1, COX-2 and iNOS, the PCR procedures were carried out using a GeneAmp 9600 PCR system (Perkin Elmer, Norwalk, CT, USA) under the following conditions: initial denaturation at $94^{\circ} \mathrm{C}$ for $5 \mathrm{~min}$, followed by 35 amplification cycles, each consisting of denaturation at $94^{\circ} \mathrm{C}$ for $45 \mathrm{~s}$, annealing at $60^{\circ} \mathrm{C}$ for $45 \mathrm{~s}$, and extension at $72^{\circ} \mathrm{C}$ for $60 \mathrm{~s}$, with an additional extension step at the end of the procedure at $72^{\circ} \mathrm{C}$ for $10 \mathrm{~min}$. For cyclophilin, the PCR procedure was under the following conditions: initial denaturation at $94^{\circ} \mathrm{C}$ for $5 \mathrm{~min}$, followed by 25 amplification cycles, each consisting of denaturation at $94^{\circ} \mathrm{C}$ for $30 \mathrm{~s}$, annealing at $55^{\circ} \mathrm{C}$, and extension at $72^{\circ} \mathrm{C}$ for $45 \mathrm{~s}$, with an additional extension step at the end of the procedure at $72^{\circ} \mathrm{C}$ for $10 \mathrm{~min}$. The final amount of RT-PCR product for each of the mRNA species was calculated densitometrically using Molecular Analyst ${ }^{\mathrm{TM}}$ version 1.4.1 (Bio-Rad, Hercules, CA, USA).

\section{Measurement of $\mathrm{PGE}_{2}$ synthesis}

In order to determine the effect of Paeonia radix on $\mathrm{PGE}_{2}$ synthesis, the amount of $\mathrm{PGE}_{2}$ in the supernatant was assessed by using a commercially 
available $\mathrm{PGE}_{2}$ competitive enzyme immunoassay kit. (Amersham Pharmacia Biotech. Inc., Piscataway, NJ, USA) Supernatant $100 \mu \mathrm{l}$ from the culture medium and the standards were put into different wells on the goat anti-mouse IgG-coated microtiter plate provided in the kit. Mouse anti-PGE ${ }_{2}$ antibody and peroxidase-conjugated $\mathrm{PGE}_{2}$ were added to each well, and the plate was incubated at room temperature with shaking for $1 \mathrm{~h}$. The wells were drained and washed, and 3,3', 5,5'-tetramethylbenzidine/hydrogen peroxide solution was added. The plate was incubated at room temperature with shaking, and the reaction was stopped after $30 \mathrm{~min}$ through the addition of $\mathrm{H}_{2} \mathrm{SO}_{4}$. The absorbance of the content of each well was then measured at a wavelength of $450 \mathrm{~nm}$.

\section{Determination of NO production}

In order to determine the effect of Paeonia radix on NO production, the amount of nitrite in the supernatant was measured by using the method based on the Griess reaction as an indicator of $\mathrm{NO}$ production. After collection of $100 \mu \mathrm{l}$ of cell culture medium, $50 \mu \mathrm{l}$ of $1 \%$ sulfanilamide was added to each well, and the plate was incubated at room temperature for $10 \mathrm{~min}$. Then $0.1 \%$ naphtylethylenediamine containing $5 \%$ phosphoric acid was added, and the plate was incubated at room temperature for $10 \mathrm{~min}$. The absorbance of the content in each well was measured at a wavelength of $450 \mathrm{~nm}$. The nitrite concentration was calculated from a nitrite standard curve generated by mixing 0 to $200 \mu \mathrm{M}$ sodium nitrite solutions with the Griess reagent. The standard curve was typically linear between 0 and $200 \mu \mathrm{M}$ of sodium nitrite.

\section{Statistical analysis}

The results are presented as the mean S.E.M. The data were analyzed by one-way ANOVA followed by Duncan's post-hoc test using SPSS. The differences were considered statistically significant at $P<0.05$.

\section{RESULTS}

\section{MTT cytotoxicity assay of Paeonia radix}

As shown in Fig. 1, the viability of cells incubated with Paeonia radix at concentrations of $0.1 \mu \mathrm{g} / \mathrm{ml}$, $1 \mu \mathrm{g} / \mathrm{ml}, 10 \mu \mathrm{g} / \mathrm{ml}, 100 \mu \mathrm{g} / \mathrm{ml}$, and 1,000 $\mu \mathrm{g} / \mathrm{ml}$ for $24 \mathrm{~h}$ was $100.54 \pm 3.55 \%, 118.88 \pm 5.16 \%, 116.04$ $\pm 6.31 \%, 128.77 \pm 9.49 \%$, and $68.26 \pm 6.34 \%$ of the control value, respectively (Fig. 1).

The present results showed that the Paeonia radix exerted no significant cytotoxicity until it reached at a concentration of $1,000 \mu \mathrm{g} / \mathrm{ml}$. Peaonia radix at concentrations of $1 \mu \mathrm{g} / \mathrm{ml}, 10 \mu \mathrm{g} / \mathrm{ml}$, and $100 \mu \mathrm{g} / \mathrm{ml}$ showed a slight enhancing effect on cell proliferation in BV2 cells.

\section{Effect of Paeonia radix on mRNA expressions of COX-1, COX-2, and iNOS}

RT-PCR analysis of the mRNA levels of COX-1, COX-2, and iNOS was performed in order to provide an estimate of the relative level of expressions of these genes. In the present study, the mRNA levels of COX-1, COX-2, and iNOS in the control cells were set as 1.00 .

The level of COX-1 mRNA following treatment with $2 \mu \mathrm{g} / \mathrm{ml}$ LPS for $24 \mathrm{~h}$ was $0.90 \pm 0.08$. The

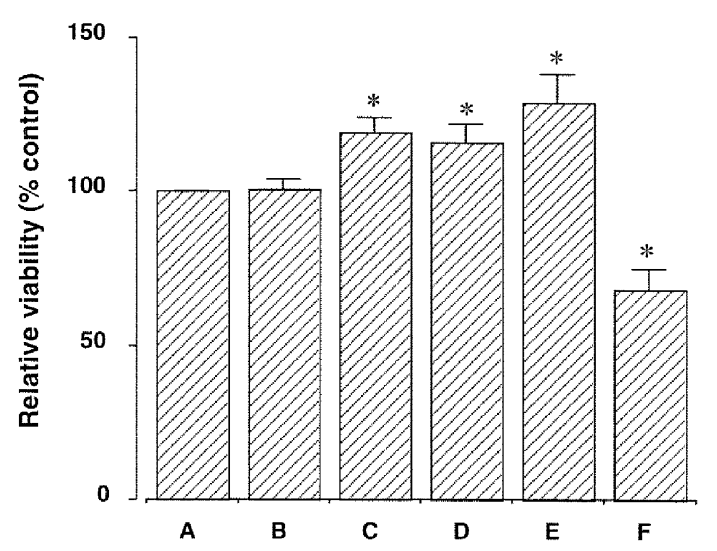

Fig. 1. Cytotoxicity of Paeonia radix. (A) Control cells, (B) $0.1 \mu \mathrm{g} / \mathrm{ml}$ Paeonia radix-treated cells, (C) $1 \mu \mathrm{g} / \mathrm{ml}$ Paeonia radix-treated cells, (D) $10 \mu \mathrm{g} / \mathrm{ml}$ Paeonia radixtreated cells, (E) $100 \mu \mathrm{g} / \mathrm{ml}$ Paeonia radix-treated cells, (F) $1,000 \mu \mathrm{g} / \mathrm{ml}$ Paeonia radix-treated cells. The data are presented as the mean \pm S.E.M. 


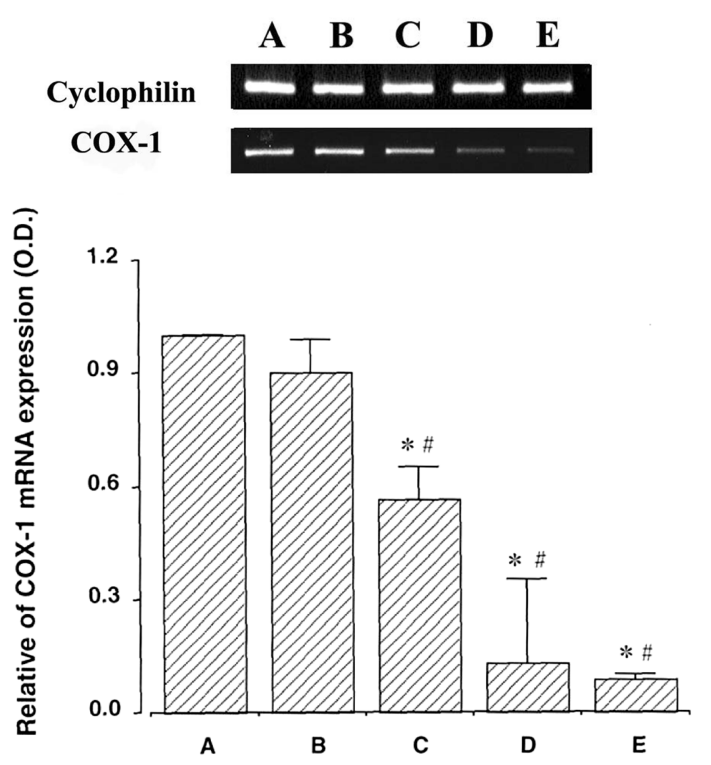

Fig. 2. Results of the mRNA level of COX-1. The cells at a density of $2 \times 10^{6}$ were treated with Paeonia radix at concentrations of $10 \mu \mathrm{g} / \mathrm{ml}$ and $100 \mu \mathrm{g} / \mathrm{ml}$ one hour before treatment of $2 \mu \mathrm{g} / \mathrm{ml}$ LPS for $24 \mathrm{~h}$. Cyclophilin mRNA was used as the internal control. ${ }^{*} P<0.05$ compared to the control. ${ }^{\#} P<0.05$ compared to the LPS-treated group. (A) Control cells, (B) $2 \mu \mathrm{g} / \mathrm{ml}$ LPStreated cells, (C) LPS and $10 \mu \mathrm{g} / \mathrm{ml}$ Paeonia radixtreated cells, (D) LPS and $100 \mu \mathrm{g} / \mathrm{ml}$ Paeonia radixtreated cells, (E) LPS and $500 \mu \mathrm{M}$ ASA-treated cells.

level of COX-1 mRNA in the cells pre-treated with Paeonia radix at concentrations of $10 \mu \mathrm{g} / \mathrm{ml}$, $100 \mu \mathrm{g} / \mathrm{ml}$, and $500 \mu \mathrm{M}$ acetylsalicylic acid (ASA) one hour before LPS exposure was decreased to $0.56 \pm 0.09,0.13 \pm 0.02$, and $0.09 \pm 0.14$, respectively (Fig. 2).

The level of COX-2 mRNA following treatment with $2 \mu \mathrm{g} / \mathrm{ml}$ LPS for $24 \mathrm{~h}$ was markedly increased to $14.74 \pm 1.24$. The level of COX-2 mRNA in the cells pre-treated with Paeonia radix at concentrations of $10 \mu \mathrm{g} / \mathrm{ml}, 100 \mu \mathrm{g} / \mathrm{ml}$, and $500 \mu \mathrm{M}$ ASA one hour before LPS exposure was decreased to $11.39 \pm$ 2.18, $9.42 \pm 1.26$, and $9.61 \pm 1.46$ respectively (Fig. 3 ).

The level of iNOS mRNA following treatment with $2 \mu \mathrm{g} / \mathrm{ml}$ LPS for $24 \mathrm{~h}$ was markedly increased to $28.58 \pm 3.18$. The level of iNOS mRNA in the cells pre-treated with Paeonia radixt at concentrations of $10 \mu \mathrm{g} / \mathrm{ml}, 100 \mu \mathrm{g} / \mathrm{ml}$, and $500 \mu \mathrm{M}$ ASA one

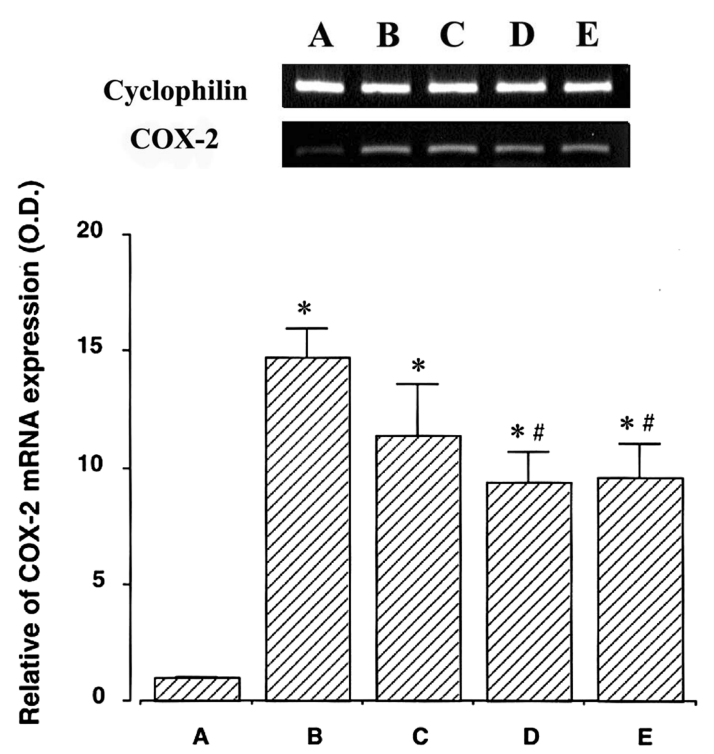

Fig. 3. Results of the mRNA level of COX-2. The cells at a density of $2 \times 10^{6}$ were treated with Paeonia radix at concentrations of $10 \mu \mathrm{g} / \mathrm{ml}$ and $100 \mu \mathrm{g} / \mathrm{ml}$ one hour before treatment of $2 \mu \mathrm{g} / \mathrm{ml}$ LPS for $24 \mathrm{~h}$. Cyclophilin mRNA was used as the internal control. ${ }^{*} P<0.05$ compared to the control. ${ }^{\#} P<0.05$ compared to the LPS-treated group. (A) Control cells, (B) $2 \mu \mathrm{g} / \mathrm{ml}$ LPStreated cells, (C) LPS and $10 \mu \mathrm{g} / \mathrm{ml}$ Paeonia radixtreated cells, (D) LPS and $100 \mu \mathrm{g} / \mathrm{ml}$ Paeonia radixtreated cells, (E) LPS and $500 \mu \mathrm{M}$ ASA-treated cells.

hour before LPS exposure was decreased to 27.91 $\pm 3.04,13.59 \pm 2.33$, and $4.13 \pm 0.99$, respectively (Fig. 4).

The present results showed that LPS exerted no significant effect on COX-1 expression, while LPS enhanced COX-2 and iNOS mRNA expressions in BV2 cells. Paeonia radix suppressed COX-1 mRNA expression and LPS-induced COX-2 and iNOS mRNA expressions in BV2 cells.

\section{Effect of Paeonia radix on $\mathrm{PGE}_{2}$ synthesis}

From $\mathrm{PGE}_{2}$ immunoassay, the amount of $\mathrm{PGE}_{2}$ from the culture medium was increased from $81.85 \pm 0.34 \mathrm{pg} / \mathrm{ml}$ to $121.60 \pm 1.69 \mathrm{pg} / \mathrm{ml}$ after $24 \mathrm{~h}$ of exposure to LPS. $\mathrm{PGE}_{2}$ synthesis was decreased to $115.11 .16 \pm 2.89 \mathrm{pg} / \mathrm{ml}, 102.01 \pm 3.65 \mathrm{pg} / \mathrm{ml}$, and $81.71 \pm 3.82 \mathrm{pg} / \mathrm{ml}$ by pre-treatment with Paeonia radix at concentrations of $10 \mu \mathrm{g} / \mathrm{ml}, 100 \mu \mathrm{g} / \mathrm{ml}$, 


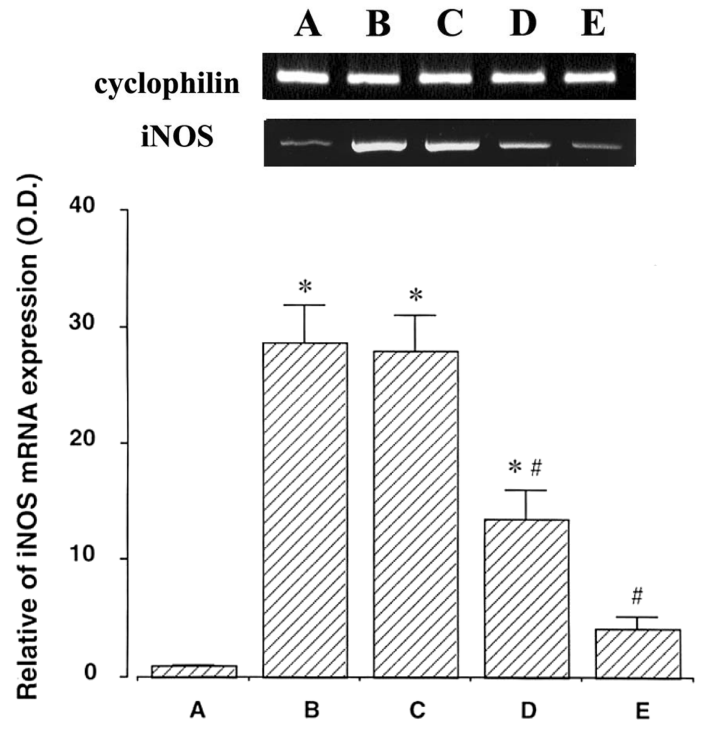

Fig. 4. Results of the mRNA level of iNOS. The cells at a density of $2 \times 10^{6}$ were treated with Paeonia radix at concentrations of $10 \mu \mathrm{g} / \mathrm{ml}$ and $100 \mu \mathrm{g} / \mathrm{ml}$ one hour before treatment of $2 \mu \mathrm{g} / \mathrm{ml}$ LPS for $24 \mathrm{~h}$. Cyclophilin mRNA was used as the internal control. ${ }^{*} P<0.05$ compared to the control. ${ }^{\#} P<0.05$ compared to the LPS-treated group. (A) Control cells, (B) $2 \mu \mathrm{g} / \mathrm{ml}$ LPStreated cells, (C) LPS and $10 \mu \mathrm{g} / \mathrm{ml}$ Paeonia radixtreated cells, (D) LPS and $100 \mu \mathrm{g} / \mathrm{ml}$ Paeonia radixtreated cells, (E) LPS and $500 \mu \mathrm{M}$ ASA-treated cells.

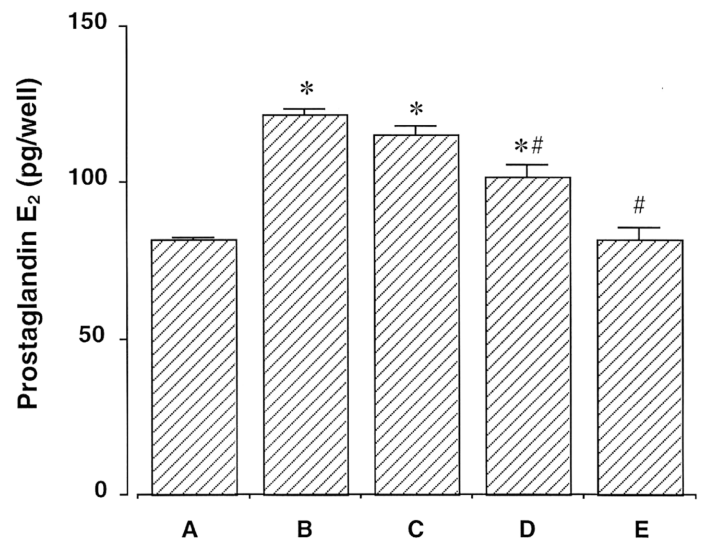

Fig. 5. Measurement of $\mathrm{PGE}_{2}$ in BV2 microglial cells. The cells at a density of $2 \times 10^{5}$ were treated with Paeonia radix at concentrations of $10 \mu \mathrm{g} / \mathrm{ml}$ and 100 $\mu \mathrm{g} / \mathrm{ml}$ one hour before treatment of $2 \mu \mathrm{g} / \mathrm{ml}$ LPS for 24 h. ${ }^{*} P<0.05$ compared to the control. ${ }^{\#} P<0.05$ compared to the LPS-treated group. (A) Control cells, (B) $2 \mu \mathrm{g} / \mathrm{ml}$ LPS-treated cells, (C) LPS and $10 \mu \mathrm{g} / \mathrm{ml}$ Paeonia radix-treated cells, (D) LPS and $100 \mu \mathrm{g} / \mathrm{ml}$ Paeonia radix-treated cells, (E) LPS and $500 \mu \mathrm{M}$ ASAtreated cells.

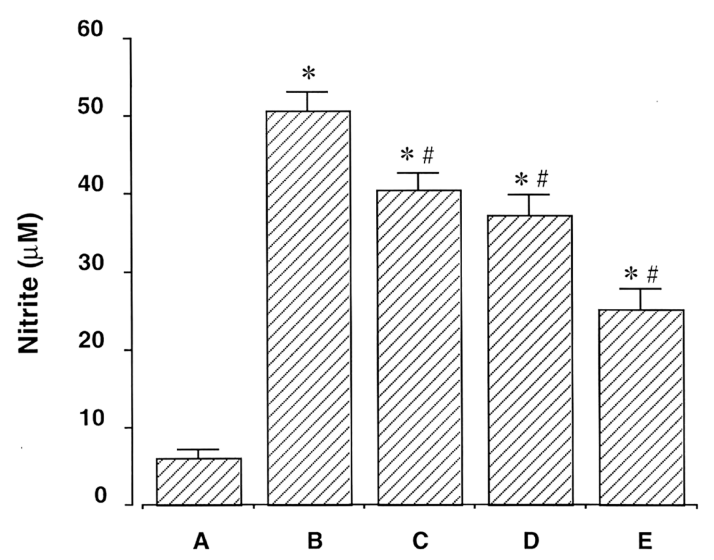

Fig. 6. Measurement of NO produced in BV2 microglial cells. The cells at a density of $2 \times 10^{5}$ were treated with Paeonia radix at concentration of $10 \mu \mathrm{g} / \mathrm{ml}$ and 100 $\mu \mathrm{g} / \mathrm{ml}$ one hour before treatment of $2 \mu \mathrm{g} / \mathrm{ml}$ LPS for 24 h. ${ }^{*} P<0.05$ compared to the control. ${ }^{\#} P<0.05$ compared to the LPS-treated group. (A) Control cells, (B) $2 \mu \mathrm{g} / \mathrm{ml}$ LPS-treated cells, (C) LPS and $10 \mu \mathrm{g} / \mathrm{ml}$ Paeonia radix-treated cells, (D) LPS and $100 \mu \mathrm{g} / \mathrm{ml}$ Paeonia radix-treated cells, (E) LPS and $500 \mu \mathrm{M}$ ASAtreated cells.

and $500 \mu \mathrm{M}$ ASA one hour before LPS exposure, respectively (Fig. 5).

The present results showed that LPS enhanced $\mathrm{PGE}_{2}$ synthesis in BV2 cells and that Paeonia radix suppressed LPS-induced $\mathrm{PGE}_{2}$ synthesis.

\section{Effect of Paeonia radix on NO production}

From the NO detection assay, the amount of nitrite from the culture medium was increased from 6.06 $\pm 0.99 \mu \mathrm{M}$ to $50.60 \pm 2.41 \mu \mathrm{M}$ after $24 \mathrm{~h}$ of exposure to LPS. NO production was decreased to $40.44 \pm$ $4.57 \mu \mathrm{M}, 37.28 \pm 2.60 \mu \mathrm{M}$, and $25.04 \pm 2.67 \mu \mathrm{M}$ by pre-treatment with Paeonia radix at concentrations of $10 \mu \mathrm{g} / \mathrm{ml}, 100 \mu \mathrm{g} / \mathrm{ml}$, and $500 \mu \mathrm{M}$ ASA one hour before LPS exposure, respectively (Fig. 6).

The present results showed that LPS enhanced NO production in BV2 cells and that Paeonia radix suppressed LPS-induced NO production.

\section{DISCUSSION}

In the present results, LPS treatment enhanced the mRNA expressions of COX-2 and iNOS, and resulted 
in the increase of $\mathrm{PGE}_{2}$ synthesis and $\mathrm{NO}$ production in mouse BV2 microglial cells.

Inflammation is a complex process that involves numerous mediators that are of cellular and plasma origin, and these mediators have elaborate and interrelated biological effects. $\mathrm{PGE}_{2}$ and $\mathrm{NO}$ are implicated in a variety of pathophysiological processes including inflammation and carcinogenesis. COX-2 and iNOS are mainly responsible for the production of large amounts of $\mathrm{PGE}_{2}$ and $\mathrm{NO}$ (Schmidt and Walter, 1994; Simon, 1999).

The present results demonstrated that the aqueous extract of Paeonia radix inhibited LPSstimulated enhancement of COX-2 mRNA expression and $\mathrm{PGE}_{2}$ synthesis in the mouse BV2 microglial cells. Elevation of COX-2 activity has also been suggested to be closely associated with the occurrence of cancers, arthritis, and several types of neurodegenerative disorders. $\mathrm{PGE}_{2}$ is a major metabolite of the COX-2 pathway. $\mathrm{PGE}_{2}$ has emerged as an important lipid mediator of inflammation and immune regulation processes, and it is also been implicated in the pathogenesis of acute and chronic inflammatory disease states (Hinz et al., 2000). Specific COX-2 inhibitors are known to attenuate the symptoms of inflammation (Crofford et al., 2000; Shao et al., 2000).

The present results demonstrated that the aqueous extract of Paeonia radix inhibited LPSstimulated enhancement of iNOS mRNA expression and NO production in the mouse BV2 microglial cells. NO has been reported to modulate the activity of COX-2 in a cGMP-independent manner, and $\mathrm{NO}$ plays a critical role in the release of $\mathrm{PGE}_{2}$ by direct activation of COX-2 (Salvemini et al., 1993). NO production has been shown as a key regulator of homeostasis and NO is known as an important mediator of inflammation in several animal models (Vane et al., 1994). Especially, the generation of NO by iNOS plays an important role in inflammation, host-defense responses, and tissue repair (Nathan and Xie, 1994). After cells are exposed to endogenous and exogenous stimulators such as LPS and viral infections, iNOS is quantitatively induced in a variety of cells. Excessive iNOS expression triggers several deleterious cellular responses and induces inflammation, sepsis, and stroke (Yui et al., 1991; Nakashima et al., 2003). Inhibition of iNOS expression in murine macrophages has been suggested as another possible mechanism of non-steroidal anti-inflammatory drugs (Amin et al., 1995).

Paeonia radix is known to nourish and restore the blood in Oriental medicine, and it has been widely used as a component of blood-building decoctions and for reducing fatigue. Paeoniflorin is a bioactive monoterpene glucoside in Paeonia radix. Paeoniflorin is known to possess an anticoagulant (Ishida et al., 1987), analgesic (Sugishita et al., 1984), anti-inflammatory and anti-allergy (Yamahara et al., 1982), and anti-oxidative activities (Kim et al., 2002).

Here in this study, we have shown that Paeonia radix extracted from Paeonia aliflora Pallas suppressed $\mathrm{PGE}_{2}$ synthesis and NO production by inhibiting LPS-stimulated enhancement of COX-2 and iNOS mRNA expressions in the BV2 microglial cells. Our present results demonstrated that Paeonia radix exerts anti-inflammatory and analgesic effects probably by suppressing COX-2 and iNOS mRNA expressions, and results in inhibition of $\mathrm{PGE}_{2}$ synthesis and NO production. Based on the present study, Paeonia radix has a potency to be developed as a new natural herbal analgesic.

\section{ACKNOWLEDGEMENTS}

This study was supported by a grant of the Oriental Medicine R\&D Project, Ministry of Health \& Welfare, Republic of Korea. (0405-OD00-0815-B050049)

\section{REFERENCES}

Amin AR, Vyas P, Attur M, Leszczynska-Piziak J, Patel IR, Weissmann G, Abramson SB. (1995) The mode of action of aspirin-like drugs: effect on 
inducible nitric oxide synthase. Proc. Natl. Acad. Sci. USA 92, 7926-7930.

Boje KM, Arora PK. (1992) Microglial-produced nitric oxide and reactive nitrogen oxides mediate neuronal cell death. Brain Res. 587, 250-256.

Chao CC, Hu S, Molitor TW, Shaskan EG, Peterson PK. (1992) Activated microglia mediate neuronal cell injury via a nitric oxide mechanism. J. Immunol. 149, 2736-2741.

Coleman RA, Smith WL, Narumiya S. (1994) International Union of Pharmacology classification of prostanoid receptors: properties, distribution, and structure of the receptors and their subtypes. Pharmacol. Rev. 46, 205-229.

Crofford LJ, Lipsky PE, Brooks P, Abramson SB, Simon LS, van de Putte LB. (2000) Basic biology and clinical application of specific cyclooxygenase-2 inhibitors. Arthritis Rheum. 43, 4-13.

Dawson TM, Dawson VL, Snyder SH. (1992) A novel neuronal messenger molecule in brain: the free radical, nitric oxide. Ann. Neurol. 32, 297-311.

Dickerson C, Undem B, Bullock B, Winchurch RA. (1998) Neuropeptide regulation of proinflammatory cytokine responses. J. Leukoc. Biol. 63, 602-605.

Gonzalez-Scarano F, Baltuch G. (1999) Microglia as mediators of inflammatory and degenerative diseases. Annu. Rev. Neurosci. 22, 219-240.

Hinz B, Brune K, Pahl A. (2000) Cyclooxygenase-2 expression in lipopolysaccharide-stimulated human monocytes is modulated by cyclic AMP, prostaglandin $\mathrm{E}_{2}$, and nonsteroidal anti-inflammatory drugs. Biochem. Biophys. Res. Commun. 278, 790-796.

Ishida H, Umino T, Tsuji K, Kosuge T. (1987) Studies on antihemorrhagic substances in herbs classified as hemostatics in Chinese medicine. VII. On the antihemorrhagic principle in Cirsium japonicum DC. Chem. Pharm. Bull. 35, 861-864.

Kim HJ, Chang EJ, Bae SJ, Shim SM, Park HD, Rhee $\mathrm{CH}$, Park JH, Choi SW. (2002) Cytotoxic and antimutagenic stilbenes from seeds of Paeonia lactiflora. Arch. Pharm. Res. 25, 293-299.

Kim HJ, Chung SK, Choi SW. (1998) Lipoxygenase inhibition and antioxidative activity of flavonoids from Paeonia moutan seeds. J. Food Sci. Nutr. 3, 315319.

Korhonen R, Lahti A, Hamalainen M, Kankaanranta H, Moilanen E. (2002) Dexamethasone inhibits inducible nitric-oxide synthase expression and nitric oxide production by destabilizing mRNA in lipopolysaccharide-treated macrophages. Mol. Pharmacol. 62, 698-704.

Kreutzberg GW. (1996) Microglia: a sensor for pathological events in the CNS. Trends Neurosci. 19, 312-318.

Kubes P, McCafferty DM. (2000) Nitric oxide and intestinal inflammation. Am. J. Med. 109, 150-158.

Lee SH, Soyoola E, Chanmugam P, Hart S, Sun W, Zhong H, Liou S, Simmons D, Hwang D. (1992) Selective expression of mitogen-inducible cyclooxygenase in macrophages stimulated with lipopolysaccharide. J. Biol. Chem. 267, 25934-25938.

Liu B, Hong JS. (2003) Role of microglia in inflammation-mediated neurodegenerative diseases: mechanisms and strategies for therapeutic intervention. J. Pharmacol. Exp. Ther. 304, 1-7.

Mitchell JA, LarkinS, Williams TJ. (1995) Cyclooxygenase-2: regulation and relevance in inflammation. Biochem. Pharmacol. 50, 1535-1542.

Nakashima MN, Ajiki K, Nakashima K, Takahashi M. (2003) Possible role of nitric oxide in anxiety following transient cerebral ischemia in mice. J. Pharmacol. Sci. 91, 47-52.

Nathan C, Xie QW. (1994) Nitric oxide synthases: roles, tolls, and controls. Cell 78, 915-918.

Salvemini D, Misko TP, Masferrer JL, Seibert K, Currie MG, Needleman P. (1993) Nitric oxide activates cyclooxygenase enzymes. Proc. Natl. Acad. Sci. USA 90, 7240-7244.

Schmidt HH, Walter U. (1994) NO at work. Cell 78, 919-925.

Shao J, Sheng H, Inoue H, Morrow JD, DuBois RN. (2000) Regulation of constitutive cyclooxygenase-2 expression in colon carcinoma cells. J. Biol. Chem. 275, 33951-33956.

Simon LS. (1999) Role and regulation of cyclooxygenase-2 during inflammation. Am. J. Med. 106, 37S-42S.

Sugishita E, Amagaya S, Ogihara Y. (1984) Studies on the combination of Glycyrrhizae Radix in ShakuyakukanzoTo. J. Pharmacobio-dyn. 7, 427-435.

Tamaya T, Sato S, Okada HH. (1986) Possible mechanism of steroid action of the plant herb extracts glycyrrhizin, glycyrrhetinic acid, and paeoniflorin: inhibition by plant herb extracts of steroid protein binding in the rabbit. Am. J. Obstet. Gynecol. 155, 
1134-1139.

Tilley SL, Coffman TM, Koller BH. (2001) Mixed messages: modulation of inflammation and immune responses by prostaglandins and thromboxanes. $J$. Clin. Invest. 108, 15-23.

Vane JR, Mitchell JA, Appleton I, Tomlinson A, Bishop-Bailey D, Croxtall J, Willoughby DA. (1994) Inducible isoforms of cyclooxygenase and nitricoxide synthase in inflammation. Proc. Natl. Acad. Sci. USA 91, 2046-2050.

Vegeto E, Bonincontro C, Pollio G, Sala A, Viappiani S, Nardi F, Brusadelli A, Viviani B, Ciana P, Maggi A. (2001) Estrogen prevents the lipopolysaccharideinduced inflammatory response in microglia. J. Neurosci. 21, 1809-1818.
Watkins LR, Wiertelak EP, Goehler LE, Smith KP, Martin D, Maier SF. (1994) Characterization of cytokine-induced hyperalgesia. Brain Res. 654, 15-26.

Yamahara J, Yamada T, Kimura H, Sawada T, Fujimura H. (1982) Biologically active principles of crude drugs. II. Anti-allergic principles in "Shoseiryu-To" anti-inflammatory properties of paeoniflorin and its derivatives. J. Pharmacobio-dyn. 5, 921-929.

Yirmiya R, Rosen H, Donchin O, Ovadia H. (1994) Behavioral effects of lipopolysaccharide in rats: involvement of endogenous opioids. Brain Res. 648, 80-86.

Yui Y, Hattori R, Kosuga K, Eizawa H, Hiki K, Kawai C. (1991) Purification of nitric oxide synthase from rat macrophages. J. Biol. Chem. 266, 12544-12547. 